\title{
GABA-Activated $\mathrm{Cl}^{-}$Channels in Astrocytes of Hippocampal Slices
}

\author{
B. A. MacVicar, ${ }^{1}$ F. W. Y. Tse, ${ }^{1}$ S. A. Crichton, ${ }^{1}$ and H. Kettenmann ${ }^{2}$ \\ 'Department of Medical Physiology, University of Calgary, Calgary, Alberta, Canada T2N 4N1, and 'Department of \\ Neurobiology, University of Heidelberg, D-6900 Heidelberg 1, Federal Republic of Germany
}

\begin{abstract}
We used kainic acid-lesioned hippocampal slices to examine glial responses to the inhibitory neurotransmitter GABA in a neuron-free environment. Slices were prepared from rats which received intracerebroventricular injections of kainic acid 1 month prior to experiments. Astrocytes (membrane potential averaged $81.4 \pm 5.5 \mathrm{mV} ; n=46$; mean \pm SD) were impaled in the CA3 region of the slice, which was completely depleted of neurons. GABA ( $1 \mathrm{~mm}$ ) application by bath perfusion depolarized membrane potential from 1 to $5 \mathrm{mV}$. The GABA-induced depolarization was not affected by a tetrodotoxin (1 $\mu \mathrm{M}) / \mathrm{high}-\mathrm{Mg}^{2+} / \mathrm{low}-\mathrm{Ca}^{2+}$ solution. Changing the $\mathrm{Cl}$ equilibrium potential by reducing extracellular $\mathrm{Cl}^{-}$greatly increased the GABA-induced depolarization. Muscimol mimicked the GABA response, while picrotoxin $(0.1 \mathrm{~mm})$, an antagonist of the GABA-activated $\mathrm{Cl}^{-}$channel, resulted in a $60 \%$ blockade. The barbiturate, pentobarbital $(0.1 \mathrm{~mm})$, and the benzodiazepine agonist, flunitrazepam (1 $\mathrm{mm}$ ), enhanced the depolarization by 60 and $40 \%$, respectively. A blocker of glial GABA uptake, $\beta$-alanine $(1 \mathrm{~mm})$, did not affect the GABA-induced membrane depolarization, indicating that the depolarization is not caused by electrogenic uptake of the amino acid. The pharmacological properties of the GABA response of astrocytes from the hippocampal slice is similar to that previously described for cultured astrocytes from rat cerebral hemispheres. Our data suggest that GABA receptors, which are coupled to $\mathrm{Cl}^{-}$channels, are also expressed by astrocytes in an intact tissue.
\end{abstract}

When the major inhibitory neurotransmitter in the CNS, GABA, is released, it binds to postsynaptic $\mathrm{GABA}_{\mathrm{A}}$ receptors and opens $\mathrm{Cl}^{-}$selective channels (Krnjevic, 1974; Bormann, 1988). The increase in the $\mathrm{Cl}^{-}$permeability of the neuronal membrane shunts any current generated by excitation and is responsible for the inhibition of the postsynaptic neuron. Depending on the relation between resting membrane potential and $\mathrm{Cl}^{-}$equilibrium potential, the neuronal membrane is either depolarized or hyperpolarized. In pyramidal cells of the hippocampus, GABA hyperpolarizes the cell when applied at the soma and depolarizes the cell when applied at the dendrites (Andersen et al., 1980).

\footnotetext{
Received Oct. 17, 1988; revised Mar. 1, 1989; accepted Apr. 18, 1989.

This work was supported by grants from Deutsche Forschungsgemeinschaft and Bundesministerium für Forschung und Technologie to H.K. and the Medical Research Council (Canada) to B.A.M. F.W.Y.T. is an Alberta Heritage Foundation for Medical Research (AHFMR) postdoctoral fellow, and B.A.M. is an AHFMR Scholar, MRC Scientist, and Sloan Fellow.

Correspondence should be addressed to Dr. B. A. MacVicar, Neuroscience Research Group, University of Calgary, 3330 Hospital Drive N.W., Calgary, Alberta, Canada T2N $4 \mathrm{Nl}$.

Copyright (C) 1989 Society for Neuroscience $0270-6474 / 89 / 103577-07 \$ 02.00 / 0$
}

Glial cells have been demonstrated to influence the size and time course of GABA-induced conductance changes in neurons by rapid removal of extracellular GABA from the synaptic region (e.g., Gallagher et al., 1983). Recent evidence from studies on cultured astrocytes and oligodendrocytes indicates that glial cells not only possess high-affinity uptake sites for GABA (Schousboe, 1981; Reynolds and Herschkovitz, 1984), but also a GABA receptor-coupled $\mathrm{Cl}^{-}$channel (Kettenmann et al., 1984, 1987; Bormann and Kettenmann, 1989). Activation of GABA receptor-coupled $\mathrm{Cl}^{-}$channels always induced a depolarization in glial cells because the intracellular $\mathrm{Cl}^{-}$in these cells is elevated above passive distribution (Kettenmann et al., 1987; Hoppe and Kettenmann, 1989). The pharmacological properties of the glial GABA receptor were characterized in cultured astrocytes from rat cortex, and it shared many similarities with the neuronal $\mathrm{GABA}_{\mathrm{A}}$ receptor. Glial GABA responses were blocked by the $\mathrm{GABA}_{\mathrm{A}}$ receptor antagonists picrotoxin and bicuculline, and were mimicked by the agonist muscimol (Kettenmann and Schachner, 1985). The glial GABA response was enhanced, as in neurons, by pentobarbital and benzodiazepine agonists (Backus et al., 1988); however, unlike the effect on neurons, inverse benzodiazepine agonists increased GABA responses in astrocytes (Backus et al., 1988; Bormann and Kettenmann, 1989). GABA-induced depolarizations in glial cells in situ have also been observed (Krnjevic and Schwartz, 1967), but these depolarizations were speculatively attributed to the release of $\mathrm{K}^{+}$ from surrounding neurons (Constanti and Galvan, 1978).

The aim of the present study was to identify glial GABA receptors in an intact tissue of the nervous system to verify that these receptors are not only expressed in cultured astrocytes, but that the expression of GABA receptor is a property of glial cells in the CNS.

\section{Materials and Methods}

Hippocampal slices. Kainic acid (KA)-induced neuronal lesions were used to produce neuron-free areas in hippocampal slices. KA $(2-3 \mu \mathrm{g})$ was injected bilaterally into the lateral ventricles of male Sprague-Dawley rats (150-200 gm). After injections, animals experienced repetitive seizures which gradually diminished in severity after a few hours. From 3 to 6 weeks after the injection, transverse hippocampal slices $(500 \mu \mathrm{m})$ were prepared from the KA-treated rats. As has been shown before (Nadler et al., 1978), KA induced virtually complete neuronal degeneration in area CA3. In cresyl violet-stained tissue (Fig. 1), the loss of pyramidal cells and the proliferation of glial cells were evident.

Cell culture. Cultures of enriched astrocytes $(>90 \%)$ were obtained from cerebral hemispheres of 0- to 2-d-old Sprague-Dawley rats according to McCarthy and De Vellis (1980), with modifications described by Keilhauer et al. (1985), and maintained in culture for 3-6 weeks. By a combination of immunocytochemical and electrophysiological techniques, it was previously shown that cells depolarized by GABA are glial fibrillary acidic protein-positive astrocytes (Kettenmann et al., 1984). 


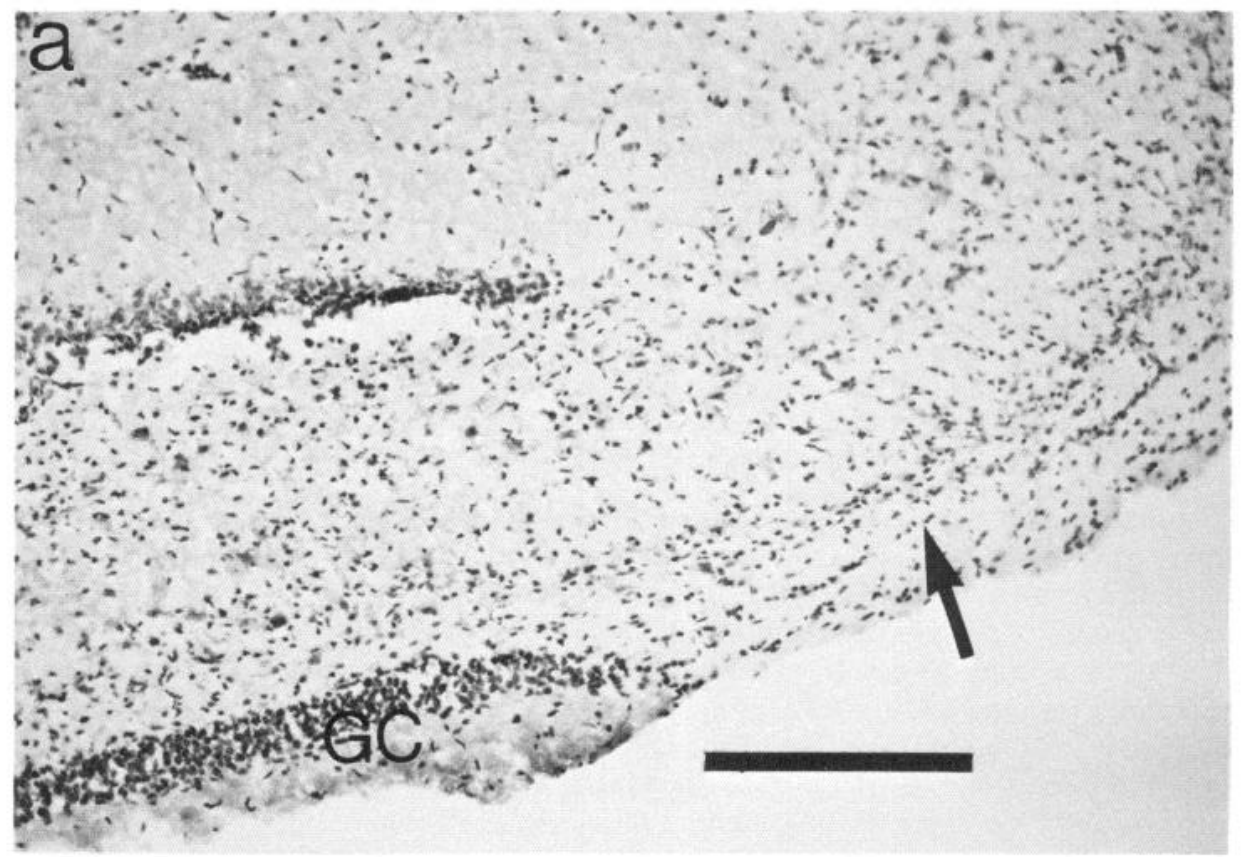

Figure 1. GFAP labeled a LY-injected glial cell in a KA-lesioned hippocampal slice. $a$, Cresyl violet-stained cryostat section of a hippocampal slice from which the glial cell illustrated in $b, c$ was recorded. There are no neurons visible in the CA3 region, which exhibits intense gliosis. The granule cell layer $(G C)$ survived the KA lesion. A recording was obtained from a glial cell (in the area indicated by the arrow) which depolarized in response to GABA and was then injected with LY. The slice was cryostat sectioned (10-15 $\mu \mathrm{m})$, and the section containing the LY-stained cell body $(b)$ was also immunohistochemically stained for GFAP $(c)$. The adjacent section was stained with cresyl violet $(a)$. GFAP-positive fibers are contained within the LY-stained cell (arrows), indicating that this cell was an astrocyte. The intensity of LY staining was greatly diminished by the diaminobenzidine reaction to visualize HRP. Scale bars: $a, 200 \mu \mathrm{m} ; b$ and $c, 20 \mu \mathrm{m}$.
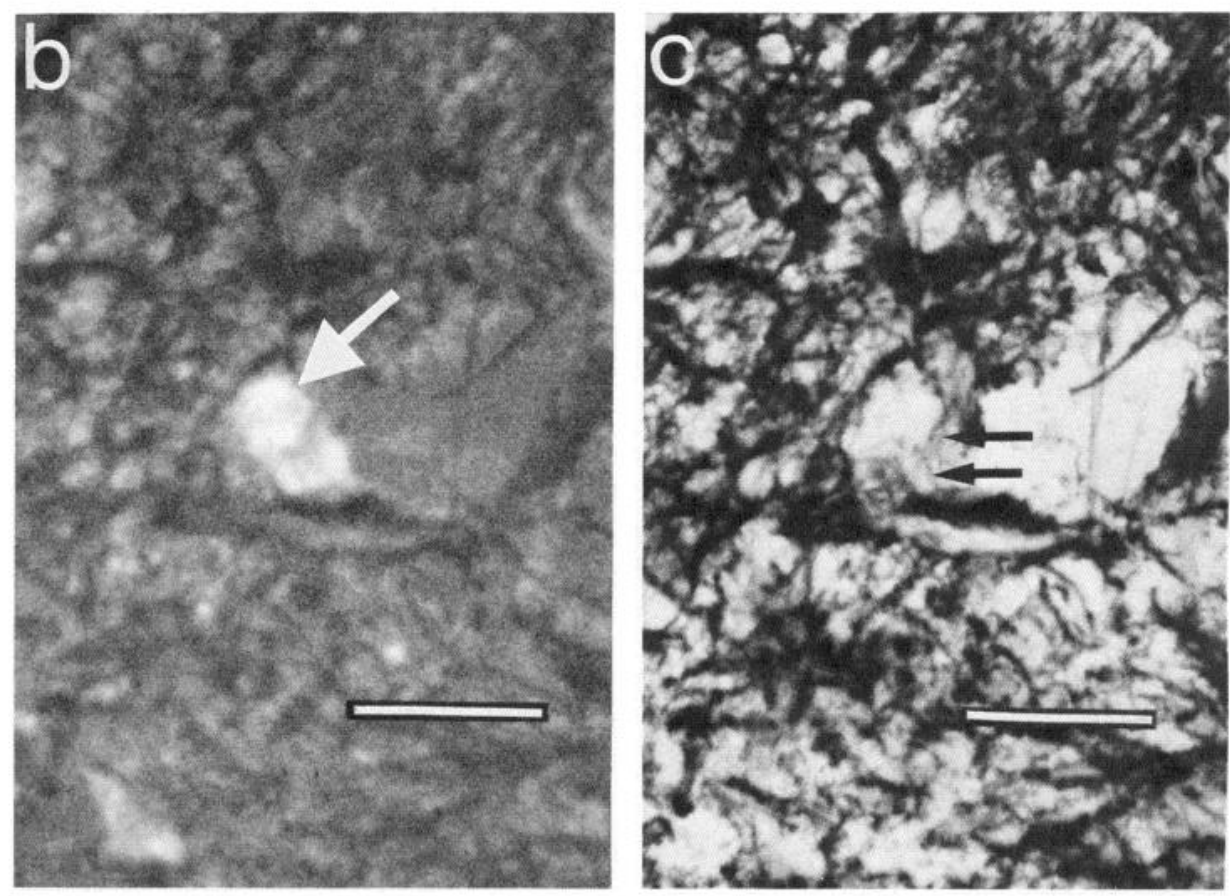

Electrophysiological procedures. Hippocampal slices $(500 \mu \mathrm{m})$ or cell cultures were maintained in a recording chamber at $35^{\circ} \mathrm{C}\left(25-30^{\circ} \mathrm{C}\right.$ for cell cultures) and were continuously perfused. Slices were submerged and perfused on one side. Cells were penetrated by $2 \mathrm{~m}$ K-acetate or $\mathrm{KCl}$-filled electrodes (resistance 40-80 M $\Omega$ ). A similar electrode recorded extracellular potentials which were subtracted from the intracellular recordings to determine the true transmembrane potential. For intracellular injection of Lucifer yellow (LY; Stewart, 1981), electrodes were filled with 4-6\% LY (Sigma, USA); 2-4 nA min of hyperpolarizing current was sufficient to stain glial cells. Electrophysiological data were amplified by conventional electrophysiological equipment, stored on the floppy disk system of a digital oscilloscope (Nicolet, Madison, USA), and plotted on an XY-plotter.

Solutions. Slices or cultures were continuously perfused via pump or gravity-feed systems during recording. For slices, the control solution contained (in mM): $\mathrm{NaCl}, 124 ; \mathrm{KCl}, 5 ; \mathrm{MgCl}_{2}, 1.3 ; \mathrm{NaHCO}_{3}, 26 ; \mathrm{CaCl}_{2}$, 2; glucose, 10 ( $\mathrm{pH} 7.35$ ). The standard salt solution for cell culture contained (in mM): $\mathrm{KCl}, 5.4 ; \mathrm{NaCl}, 116.4 ; \mathrm{NaH}_{2} \mathrm{PO}_{4}, 1.0 ; \mathrm{MgSO}_{4}, 0.8$; $\mathrm{CaCl}_{2}, 1.8$; D-glucose, 5.6; $\mathrm{NaHCO}_{3}, 26.2$. The TTX/high- $\mathrm{Mg}^{2+} /$ low$\mathrm{Ca}^{2+}$ solution was the control solution modified to include $1 \mu \mathrm{M}$ TTX, $10 \mathrm{~mm} \mathrm{Mg}^{2+}$, and $0.2 \mathrm{mM} \mathrm{Ca}^{2+} . \mathrm{NaCl}(124 \mathrm{~mm})$ was replaced with $\mathrm{Na}$ gluconate $(124 \mathrm{~mm})$ in experiments to reduce extracellular $\mathrm{Cl}^{-}$. The following substances were added to the salt solution: $\operatorname{GABA}(1,10 \mathrm{~mm})$, muscimol (1 $\mathrm{mM})$, picrotoxin (0.1 $\mathrm{mM})$, flunitrazepam (0.1-1 mM), pentobarbital $(0.1 \mathrm{~mm}), \beta$-alanine $(1 \mathrm{~mm})$.

GFAP staining. After recordings were obtained from cells injected with LY, slices were fixed in $4 \%$ paraformaldehyde in phosphate buffer $(0.1 \mathrm{M})$ for $24 \mathrm{hr}$. Following infiltration with $20 \%$ sucrose, sections (10$15 \mu \mathrm{m}$ ) were cut on a cryostat and observed on a fluorescence microscope to determine which section(s) had the LY-stained cell. Immunohistochemical staining for glial fibrillary acidic protein (GFAP) was accomplished using a Vectastain kit (Vector Lab.) and a monoclonal antibody for GFAP (Labsystems, Helsinki). The final visualization of the HRP was accomplished using a diaminobenzidine reaction. This, however, 

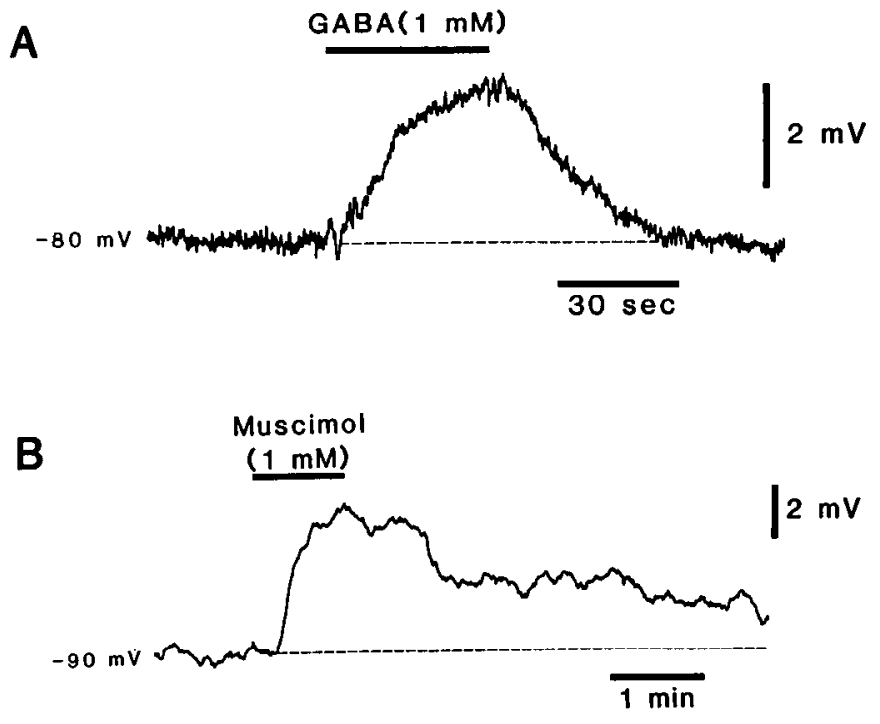

Figure 2. GABA- and muscimol-induced membrane depolarization. $A$, A stable intracellular recording was obtained from a glial cell in a KA-lesioned slice. GABA (1 mM) was applied as indicated by bar and reversibly depolarized glial membrane potential. The resting membrane potential is indicated at the beginning of the trace. $B$, In another cell, muscimol ( $1 \mathrm{~mm})$, an agonist, was applied as indicated and also reversibly depolarized the glial cell.

greatly diminished the LY fluorescence. Adjacent sections were stained with cresyl violet to examine the extent of the KA-induced lesion.

\section{Results}

\section{Identification of astrocytes in the hippocampal slice}

Hippocampal slices were obtained from rats which had received an injection of KA 3-6 weeks prior to the experiment. Cells were impaled in the CA3 area, which was free of neurons as described previously (MacVicar et al., 1987). Neurons were rarely impaled (e.g., only in 3 out of several hundred impalements; in these cases, the slice was then no longer used because it contained viable neurons). Stable penetration of glial cells resulted in the recording of a very negative resting membrane potential $(81.4 \pm 5.5 \mathrm{mV}$; mean $\pm \mathrm{SD} ; n=46)$ with no apparent spike or postsynaptic potential activity.

\section{$G A B A$-induced depolarizations in the slice}

In all cells examined, application of GABA ( 1 or $10 \mathrm{~mm}$ ) for 1 min depolarized the membrane potential reversibly (Fig. $2 A$ ). The maximum depolarization induced by 1 or $10 \mathrm{~mm}$ GABA was $1.6 \pm 0.7 \mathrm{mV}( \pm \mathrm{SD} ; n=10)$, or $3.5 \pm 0.9( \pm \mathrm{SD} ; n=$ 9), respectively. In 5 experiments, we verified that this GABAinduced depolarization also occurred when synaptic and spike activities in the slices were minimized by superfusing a "low-Ca ${ }^{2+} \mathrm{TTX} / \mathrm{high}-\mathrm{Mg}^{2+}$ solution" (see Materials and Methods; data not shown); under these conditions the mean depolarization induced by $1 \mathrm{~mm}$ GABA was $1.5 \pm 0.7$ ( $\pm \mathrm{SD} ; n-$ 5).

In three out of three experiments we observed that the GABAinduced depolarization could be reversed (Fig. 3) when the membrane potential was depolarized to approximately $-15 \mathrm{mV}$ during a sustained application of $50 \mathrm{~mm}$ extracellular $\mathrm{KCl}$ (Fig. 3 ; in "TTX solution/high $\mathrm{Mg}^{2+} /$ low $\mathrm{Ca}^{2}$ "). Furthermore, altering the equilibrium potential for $\mathrm{Cl}^{-}\left(E_{\mathrm{C}}\right)$ by replacing extracellular $\mathrm{Cl}^{-}$with gluconate, an impermeant anion, increased the GABA
A High $\mathrm{K}^{+}$

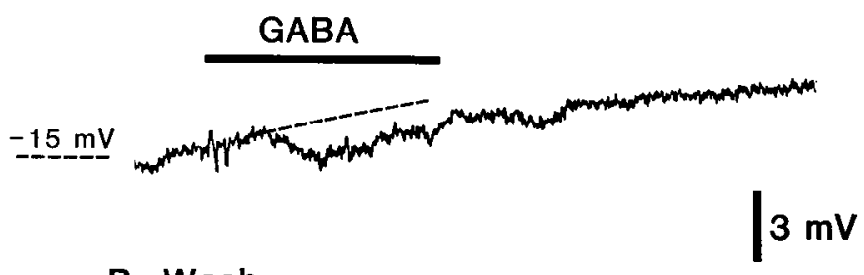

B Wash

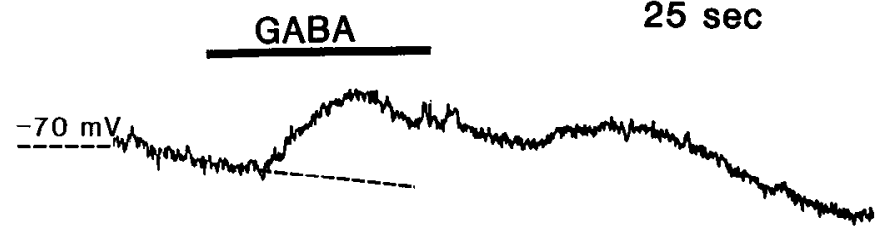

Figure 3. Reversal of GABA depolarizations in high $\mathrm{K}^{+}$. A stable intracellular recording was obtained from a glial cell in $5 \mathrm{mM} \mathrm{K}^{+}$, then $\mathrm{K}^{+}$was increased to $50 \mathrm{~mm}$ by equimolar replacement of $\mathrm{Na}^{+}$with $\mathrm{K}^{+}$. When membrane potential was approximately $-15 \mathrm{mV}$ (after $10 \mathrm{~min}$ ), GABA (1 mM) was bath-applied and caused a membrane hyperpolarization. Membrane potential was still slowly drifting and is indicated by the dotted line. Extracellular $\mathrm{K}^{+}$was then decreased to $5 \mathrm{~mm}$, and GABA now caused a depolarization as membrane potential was slowly recovering to control levels.

( $1 \mathrm{mM}$ )-induced depolarization from 1.6 to $7 \mathrm{mV}$ ( $n=4$; Fig. $4 A$ ). The above experiments suggest that GABA is activating a $\mathrm{Cl}^{-}$conductance and the normal $E_{\mathrm{Cl}}$ in glial cells is less negative than membrane potential. Six cells from these experiments were stained by injecting $-2 \mathrm{nA}$ of $\mathrm{LY}$ for $2.0 \mathrm{~min}$. As described earlier (Gutnick et al., 1981; Connors et al., 1984), the dye spread to adjacent cells indicating electrical coupling. Some cells were subsequently identified as astrocytes by immunohistochemically staining the slice for GFAP, a specific glial marker (Fig. 1).

\section{Pharmacology of GABA-induced depolarizations}

We tested the effect of an agonist, an antagonist, and 2 modulators of neuronal $\mathrm{GABA}_{\mathrm{A}}$ receptors to compare the GABA responses in hippocampal astrocytes with those in neurons and cultured glial cells. Muscimol, $(1 \mathrm{mM})$, a GABA $\mathrm{A}_{\mathrm{A}}$ receptor agonist that is not taken up in brain slices (Korn and Dingledine, 1986), mimicked the action of GABA by inducing a maximum depolarization of $2.7 \pm 1.8 \mathrm{mV}$ (Fig. $2 B ; n=5$ ). Picrotoxin $(0.1$ $\mathrm{mM}$ ), which has been shown to block the GABA-coupled $\mathrm{Cl}^{-}$ channel in neurons (Barker et al., 1983), reversibly reduced the GABA-induced depolarization in the astrocytes by $40 \%(n=4$; Fig. $4 B$ ) compared with a control obtained from the same cell. Pentobarbital, a barbiturate, reversibly enhanced the GABAinduced depolarization by $60 \%(n=9$; Fig. 5$)$; a similar action on the neuronal GABA $\mathrm{A}_{\mathrm{A}}$ receptor has been reported (Study and Barker, 1981). Flunitrazepam (1 mM), a benzodiazepine receptor agonist, enhanced the GABA response by $40 \%(n=4$; Fig. 5), showing further similarities to the neuronal $\mathrm{GABA}_{\mathrm{A}}$ receptor (Bormann and Sakmann, 1984). A blocker of GABA uptake, $\beta$-alanine (1 mM) (Shon and Kelly, 1974; Bowery et al., 1979; Schousboe, 1981), did not affect the size of the GABA-induced depolarization (data not shown; $n=3$ ). The pharmacological properties of the GABA receptor in astrocytes from hippocampus are thus similar to those of the $\mathrm{GABA}_{\mathrm{A}}$ receptor in neurons and the GABA receptor in cultured astrocytes. 
Figure 4. GABA-induced membrane depolarizations are dependent on the $\mathrm{Cl}^{-}$gradient and blocked by picrotoxin. During an intracellular recording from a glial cell in a KA-lesioned slice, GABA (1 mM) was applied as indicated by bar. Three responses to GABA were obtained from the same cell and were superimposed. The individual applications were separated by at least $10 \mathrm{~min}$ to avoid progressive desensitization. First, as a control, GABA was applied. For the next application, the experimental solution (gluconate-low $\mathrm{Cl}^{-}$or picrotoxin) was applied for $2-10 \mathrm{~min}$ and the effect of GABA was again tested in the presence of the experimental solution. Resting membrane potential was not affected by either $\mathrm{Cl}^{-}$replacement or picrotoxin. After a $20 \mathrm{~min}$ wash with normal bathing solution, GABA was again applied. $A$, Reducing extracellular $\mathrm{Cl}^{-}$by replacing most $\mathrm{Cl}^{-}$with an impermeant anion, gluconate, greatly enhanced the depolarization from GABA (1 $\mathrm{mm}$ ) application. Note also that the depolarization in gluconate quickly begins to desensitize. This is also observed during GABA applications on cultured glial cells. $B$, Picrotoxin $(0.1$ mM) reversibly decreased the GABAinduced depolarization. Therefore, the glial GABA response is altered by both changing the $\left[\mathrm{Cl}^{-}\right]$and by pharmacologically blocking the $\mathrm{Cl}^{-}$channel with picrotoxin.
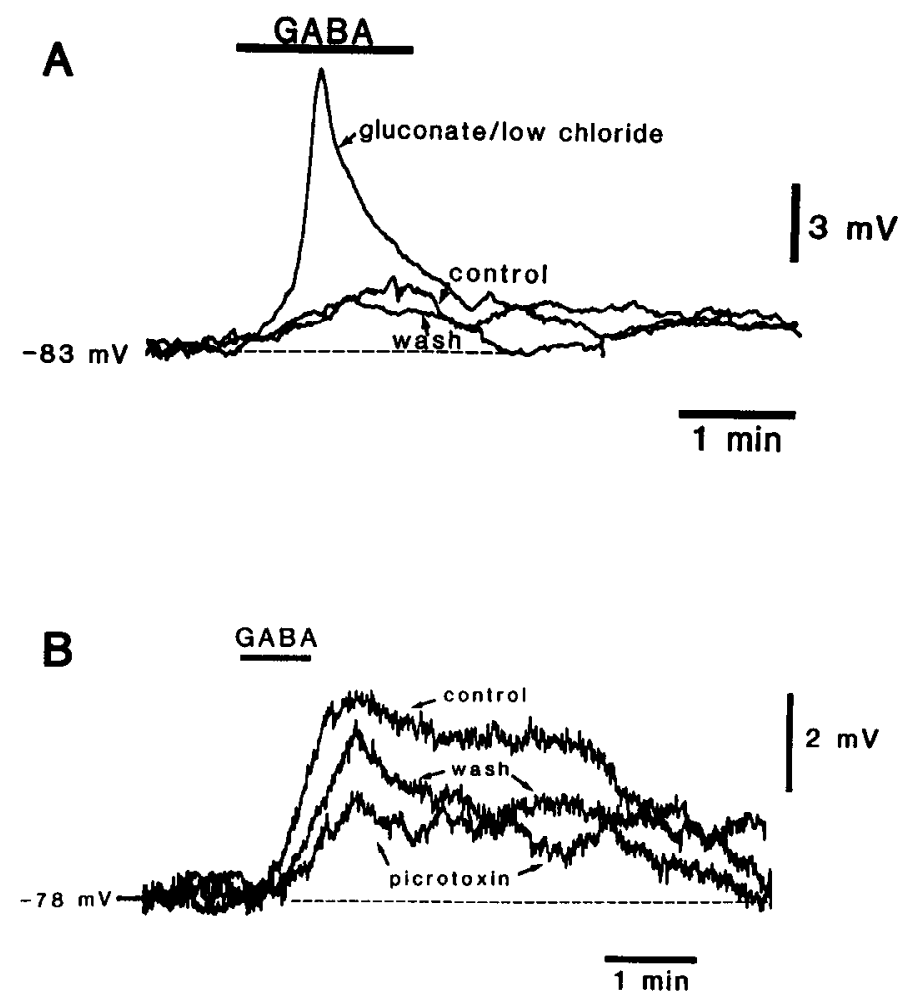

Comparison of glial GABA responses in situ and in vitro

The GABA-induced depolarizations in astrocytes from the rat hippocampal slice were much smaller in size than those described for cultured astrocytes from rat cortex (Kettenmann et al., 1984). This difference can be attributed to 2 aspects: first, the diffusion of applied GABA to astrocytes is slower in the slice than in culture because of the thickness of the slice; second, there may be a difference in $E_{\mathrm{Cl}}$. The contribution from the former was directly tested. To obtain an estimate of the velocity of GABA diffusion in the slice, we increased the extracellular $\mathrm{K}^{+}$concentration from 5 to $50 \mathrm{~mm}$ and recorded the resulting membrane depolarization of an astrocyte (not shown). The membrane potential depolarized by $60 \mathrm{mV}$ and reached a plateau within $4.5 \mathrm{~min} ; 90 \%$ of the depolarization was reached within $3.5 \mathrm{~min}$. We then compared GABA- and $\mathrm{K}^{+}$-induced depolarization in cultured astrocytes and varied the velocity of application by varying the speed of bath perfusion. The exchange rate of the bath was monitored by recording the time course of the depolarization induced by an increase in the extracellular $\mathrm{K}^{+}$concentration. An exchangc ratc of at lcast $90 \%$ of the bathing solutions within $15 \mathrm{sec}$ was required to elicit GABA(1mM)induced depolarizations, which were larger than $10 \mathrm{mV}$. A reduction of the perfusion rate from $90 \%$ exchange/ $10 \mathrm{sec}$ to $90 \%$ exchange $/ 60 \mathrm{sec}$ in culture to mimic the slow diffusion of GABA into the slice reduced the GABA-induced depolarization from $>20 \mathrm{mV}$ to $<5 \mathrm{mV}$ (Fig. 6). We conclude that slow application of GABA results only in small depolarizations even at optimal GABA concentrations.

\section{Discussion}

Presence of glial $G A B A$ receptors in situ

Previous studies have already shown that glial cells in the intact tissue were depolarized by GABA (Krnjevic and Schwart 2,1967 ; Constanti and Galvan, 1978). It was, however, suggested that the depolarization is caused by either electrogenic uptake of GABA (e.g., Krnjevic, 1984) or by the increase of extracellular $\mathrm{K}^{+}$concentration released from adjacent neurons (Constanti and Galvan, 1978). In these experiments, however, the CA3 neurons have been lesioned by a KA injection. The GABA-induced depolarization was not blocked by inhibiting any possible residual neuronal activity or synaptic transmission with a combination of TTX, raised extracellular $\mathrm{Mg}^{2+}$, and reduced $\mathrm{Ca}^{2+}$. For cultured astrocytes, it has been unequivocally demonstrated that the GABA-induced depolarization is caused by the opening of $\mathrm{Cl}^{-}$channels activated by GABA (Kettenmann et al., 1987; Bormann and Kettenmann, 1989). GABA responses in glial cells in the slice could be enhanced by the barbiturate pentobarbital and blocked by the $\mathrm{GABA}_{\mathrm{A}}$ receptor antagonist picrotoxin. In addition, the blocker of glial GABA uptake, $\beta$-alanine (Shon and Kelly, 1974; Bowery et al., 1979), did not affect the GABAinduced depolarization, indicating that electrogenic uptake did not cause the depolarization. Also, muscimol, a $\mathrm{GABA}_{\mathrm{A}}$ agonist which is not taken up in brain slices (Johnston et al., 1978; White and Snodgrass, 1979; Korn and Dingledine, 1986) depolarized glial cells in this study. Therefore, the pharmacological properties of glial GABA responses in the KA-lesioned slice are in line with those described for cultured astrocytes and are thus 

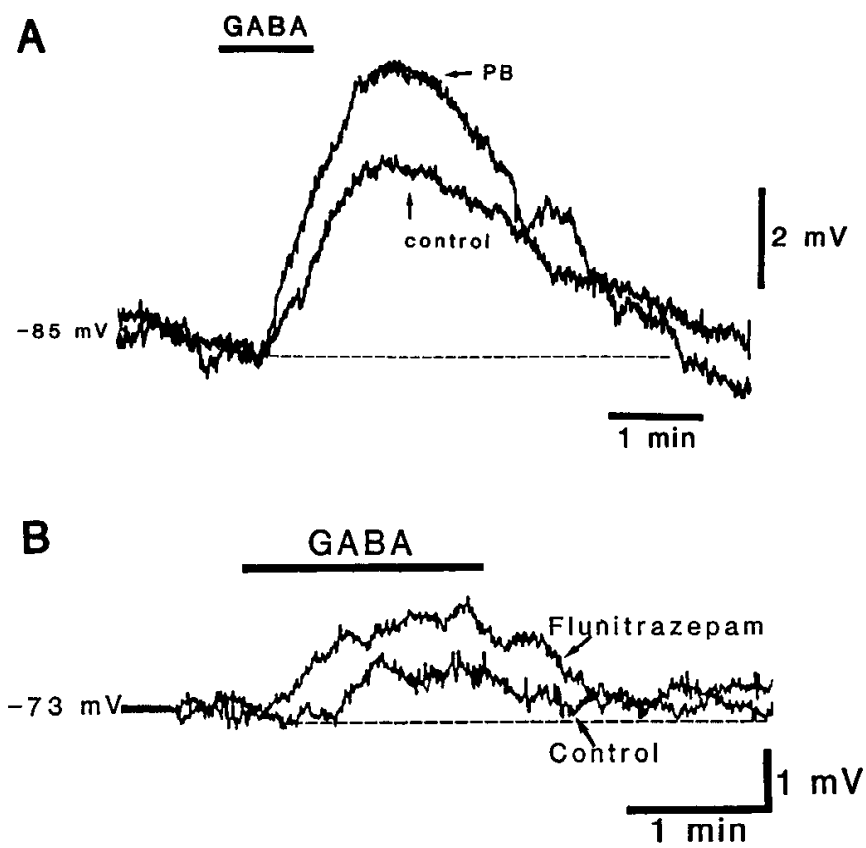

Figure 5. Effect of pentobarbital and flunitrazepam on the GABAinduced depolarization. GABA alone was applied for the control response; the experimental solutions (pentobarbital or flunitrazepam) were applied for $2 \mathrm{~min}$ and the response to GABA was then tested again. $A$, In the presence of $0.1 \mathrm{~mm}$ pentobarbital $(P B)$, the GABA-induced depolarization was enhanced compared with the control. $B$, Similar to the response in $A$, the addition of flunitrazepam ( $1 \mathrm{~mm})$ enhanced the amplitude of the GABA-induced depolarization. Effects of both drugs were reversible upon wash.

similar to the properties of the neuronal $\mathrm{GABA}_{\mathrm{A}}$ receptor. This suggests that the expression of $\mathrm{GABA}_{\mathrm{A}}$ receptors in astrocytes is not induced by the culture conditions, but is an intrinsic property of these cells. We cannot exclude, however, that the lack of neurons and the reactive gliosis might affect the expression of channels in astrocytes.

\section{Sensitivity of the glial $G A B A$ receptor}

In this study we have used higher concentrations of GABA than similar studies performed on neurons or on cultured astrocytes and have detected only small changes in the resting membrane potential of astrocytes in the slice. While the single-channel properties of the GABA receptors in neurons and cultured astrocytes are similar (Bormann and Kettenmann, 1989), several properties of glial cells in an intact tissue make it difficult to detect membrane depolarizations upon GABA receptor activation. First, glial cells are strongly electrically coupled, thus forming a large syncytium (Gutnick et al., 1981; Kettenmann and Ransom, 1988). When GABA is applied, it first activates receptors located on the surface of the slice. However, because of the extensive coupling, the depolarization is strongly attenuated by the glial cells located deeper in the slice. Subsequently, when GABA has penetrated further into the slice, receptors on the surface are inactivated and thus attenuate the depolarization of the glial cells deeper in the slice. The extensive coupling also results in small membrane potential changes when substances are applied iontophoretically, since only a relatively small membrane area of the whole syncytium can be activated as it has been done in cortical glial cells (Krnjevic and Schwartz, 1967). Second, the input resistance of glial cells is much lower than
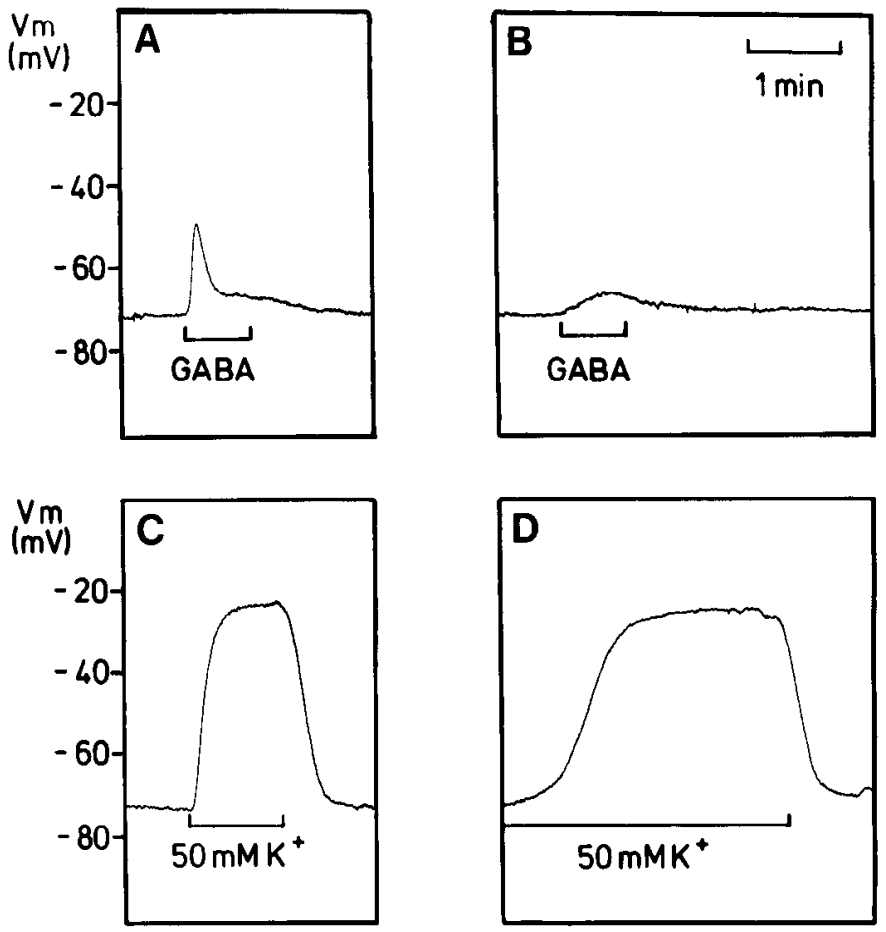

Figure 6. Influence of the bath perfusion speed on the size of the GABA-induced depolarization in culturcd astrocytes. Membrane potential $\left(\mathrm{V}_{m}\right)$ was recorded from a cultured astrocyte from rat cortex. In $A$, GABA (1 mM) was applied as indicated by $b a r$, and in $B$, with the same speed of bath perfusion, $\left[\mathrm{K}^{+}\right]$was increased from 5.4 to $50 \mathrm{~mm}$. In $C$ and $D$, the velocity of bath perfusion was reduced and GABA $(C)$ resulted in a smaller depolarization. The slowed perfusion speed is reflected in the slower depolarization induced by the increase in $\left[\mathrm{K}^{+}\right]$ $(D)$.

that of neurons. This results in a smaller membrane depolarization when comparable numbers of receptors are activated. Third, the normal $E_{\mathrm{Cl}}$ in glial cells in the slice preparations may be closer to resting membrane potential. Shifting $E_{\mathrm{Cl}}$ to a more depolarized potential by reducing extracellular $\mathrm{Cl}^{-}$greatly enhanced the amplitude of the depolarization. These 3 factors may explain why GABA responses can be easily detected in neurons, but not in glial cells of a slice preparation. Compared with cultured astrocytes, responses are smaller because of the slow diffusion of the transmitter in the slice when applied by bath exchange. We obtained an estimate of the time course for diffusion in the slice during a solution change by increasing extracellular $\mathrm{K}^{+}$and recording the membrane depolarization of an astrocyte. Diffusion into the slice greatly reduces the rate at which agents can be introduced onto cells. Thus, activating receptors by slowly increasing the concentration in the slice led to a small depolarization of the glial cell, in contrast to a steplike solution change causing a large depolarization in culture (see Fig. 6). Considering these less-than-optimal conditions for detection of GABA responses, we conclude that glial cells could express GABA receptors in significant amounts and that they could be functionally relevant. Receptor activation leads only to small depolarization, but could locally induce large $\mathrm{Cl}^{-}$currents (Kettenmann et al., 1988). The presence of $\mathrm{GABA}_{\mathrm{A}}$ receptors and $\mathrm{GABA}$-activated $\mathrm{Cl}^{-}$currents in glial cells may have widespread implications for GABA-binding studies and GABAactivated $\mathrm{Cl}^{-}$flux studies. In most biochemical studies in the $\mathrm{CNS}$, it has been assumed that GABA-activated $\mathrm{Cl}^{-}$channels 


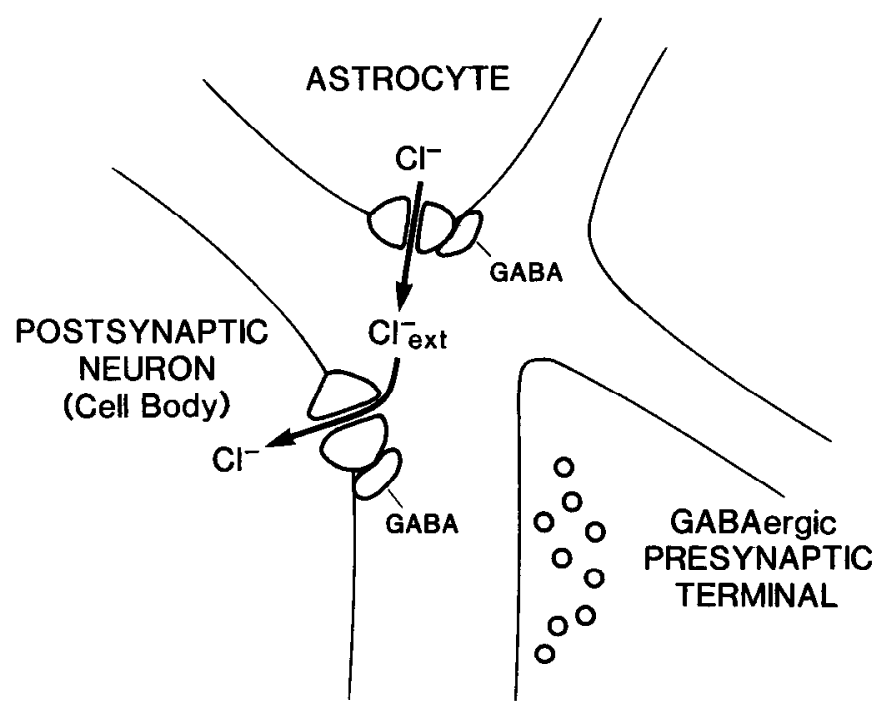

Figure 7. Hypothetical function of glial GABA receptors. The diagram displays the presumptive spatial arrangement of glial and neuronal GABA receptors necessary to explain the role of astrocytes in the $\mathrm{Cl}^{-}$homeostasis. The close vicinity of an astrocytic process at a synapse to a neuron is assumed. At lower right is a synaptic region marked by the synaptic vesicles. This part illustrates that GABA is released from the presynaptic terminal and activates GABA receptors at the neuronal postsynaptic membrane. The GABA receptor $\mathrm{Cl}^{-}$channel opens and triggers a $\mathrm{Cl}^{-}$ flux from the extracellular space into the neuron. GABA also activates astrocytic $\mathrm{GABA}$ receptors, which leads to an efflux of $\mathrm{Cl}^{-}$from the glial cell into the extracellular space. Movements of other ions, particularly $\mathrm{K}^{+}$, may also occur, and extracellular $\left[\mathrm{K}^{+}\right]$could also increase due to $\mathrm{K}^{+}$efflux from GABA-depolarized astrocytes.

are expressed only on neurons. This work indicates that there should be more caution attributing a purely neuronal site for some neurotransmitters. There is also evidence for glutamate (kainate type; MacVicar et al., 1988) and muscarinic (S. A. Crichton and B. A. MacVicar, unpublished observations) receptors on glial cells in the KA-lesioned hippocampal slice.

\section{Function of glial GABA receptors}

The possibility that GABA receptors are expressed by glial cells in an intact tissue leads to the question of their functional role. These receptors could serve as a signal from an inhibitory neuron to an adjacent glial cell. Furthermore, we present, in the following, a hypothesis by which glial cells could be enabled to regulate the extracellular $\mathrm{Cl}^{-}$concentration in the vicinity of a GABAergic synapse (Fig. 7).

We assume that glial GABA receptors are concentrated at processes or endfeet facing the synaptic cleft of a GABAergic synapse. When neuronal GABA receptors are activated, it leads to an influx of $\mathrm{Cl}^{-}$into those neurons which hyperpolarize upon application of $\mathrm{GABA}$. The $\mathrm{Cl}$ influx leads, as a consequence, to a decrease in extracellular $\left[\mathrm{Cl}^{-}\right]$as described by Müller et al. (1988). In contrast, activation of glial GABA rcceptors lcads to an efflux of $\mathrm{Cl}^{-}$. Glial cells could thereby be enabled to regulate $\left[\mathrm{Cl}^{-}\right]$. This mechanism of extracellular $\mathrm{Cl}^{-}$regulation could serve to stabilize $\left[\mathrm{Cl}^{-}\right]$in the synaptic cleft at times of high inhibitory activity and supports the concept of glial cells being regulatory units of extracellular ion concentrations. Since the efflux of $\mathrm{Cl}^{-}$ is also accompanied by an efflux of $\mathrm{K}^{+}$(Kettenmann et al., 1988), a rise in extracellular $\left[\mathrm{K}^{+}\right]$should be observed during GABA application. An efflux of $\mathrm{K}^{+}$has been observed during a KA- induced depolarization of glial cells (MacVicar et al., 1988). This could lead to a $\mathrm{K}^{+}$-induced depolarization of neurons, and indeed, hyperpolarizing IPSPs are followed by a depolarization (Diesz and Prince, 1989). GABA-evoked depolarizations of neurons could reflect a glial-generated $\left[\mathrm{K}^{+}\right]$increase.

\section{References}

Andersen, P., R. Dingledine, L. Gjerstad, I. A. Langmoen, and A. M. Laursen (1980) Two different responses of hippocampal pyramidal cells to application of gamma-aminobutyric acid. J. Physiol. (Lond.) 305: 279-296.

Backus, K. H., H. Kettenmann, and M. Schachner (1988) Effect of benzodiazepines and pentobarbital on the GABA-induced depolarization in cultured astrocytes. Glia $1: 132-140$.

Barker, J. L., R. N. McBurney, and D. A. Mathers (1983) Convulsantinduced depression of amino acid responses in cultured mouse spinal neurones studied under voltage clamp. Br. J. Pharmacol. 80: 619629.

Bormann, J. (1988) Electrophysiology of $\mathrm{GABA}_{\mathrm{A}}$ and $\mathrm{GABA}_{\mathrm{B}}$ receptor subtypes. Trends Neurosci. 11: 112-116.

Bormann, J., and H. Kettenmann (1989) Patch clamp study of GABA receptor $\mathrm{Cl}^{-}$channels in cultured astrocytes. Proc. Natl. Acad. Sci. USA (in press).

Bormann, J., and B. Sakmann (1984) Properties of inhibitory Cl channels and the action of diazepam. IUPHAR 9th Int. Cong. Pharmacol., London, Abstr. S13-S14.

Bowery, N. G., D. A. Brown, R. D. White, and G. Yamini (1979) $\left[\mathrm{H}^{3}\right]$ Gamma-amino butyric acid uptake into neuroglial cells of rat superior cervical sympathetic ganglia. J. Physiol. (Lond.) 293: 51-74.

Connors, B. W., L. S. Benardo, and D. A. Prince (1984) Carbon dioxide sensitivity of dye coupling among glia and neurons of the neocortex. J. Neurosci. 4: 1324-1330.

Constanti, A., and M. Galvan (1978) Amino-acid-evoked depolarization of electrically inexcitable neuroglial cells in the guinea pig olfactory cortex slice. Brain Res. 153: 183-187.

Deisz, R. A., and D. A. Prince (1989) Frequency dependent depression of inhibition in the guinea pig neocortex in vitro by $\mathrm{GABA}_{\mathrm{B}}$ receptor feedback on GABA release. J. Physiol. (Lond.) (in press).

Gallagher, J. P., J. Nakamura, and P. Shinnick-Gallagher (1983) Effects of glial uptake and desensitization on the activity of $\gamma$-aminobutyric acid (GABA) and its analogs at the cat dorsal root ganglion. J. Pharmacol. Exp. Ther. 26: 876-884.

Gutnick, M. J., B. W. Conners, and B. R. Ransom (1981) Dye-coupling between glial cells in the guinea pig neocortical slice. Brain Res. 213: 486-492.

Hoppe, D., and H. Kettenmann (1989) GABA triggers a $\mathrm{Cl}^{-}$efflux from cultured mouse oligodendrocytes. Neurosci. Lett. (in press).

Johnston, G. A. R., S. M. E. Kennedy, and D. Lodge (1978) Muscimol uptake, release and binding in rat brain slices. J. Neurochem. 34: 1519-1523.

Keilhauer, G., D. H. Meier, S. Kuhlmann, J. Nieke, and M. Schachner (1985) Astrocytcs support incomplctc differentiation of an oligodendrocyte precursor cell. EMBO J. 4: 2499-2504.

Kettenmann, H., and B. R. Ransom (1988) Electrical coupling between astrocytes and between oligodendrocytes in mammalian cell cultures. Glia 1: 64-73.

Kettenmann, H., and M. Schachner (1985) Pharmacological properties of GABA, glutamate and aspartate induced depolarizations in cultured astrocytes. J. Neurosci. 5: 3295-3301.

Kettenmann, H., K. H. Backus, and M. Schachner (1984) Aspartate, glutamate and gamma-aminobutyric acid depolarize cultured astrocytes. Neurosci. Lett. 52: 25-29.

Kettenmann, H., K. H. Backus, and M. Schachner (1987) GABA opens $\mathrm{Cl}^{-}$channels in cultured astrocytes. Brain Res. 404: 1-9.

Kettenmann, H., K. H. Backus, and M. Schachner (1988) GABA receptors on cultured astrocytes. In Glial Cell Receptors, H. K. Kimelberg, ed., pp. 95-106, Raven Press, New York.

Korn, S. J., and R. Dingledine (1986) Inhibition of GABA uptake in the rat hippocampal slice. Brain Res. 368: 247-255.

Krnjevic, K. (1974) Chemical nature of synaptic transmission in vertebrates. Physiol. Rev. 2: 419-540.

Krnjevic, K. (1984) Some functional consequences of $\mathrm{Na}^{+}$-linked GABA uptake. Neurosci. Lett. 47: 283-287. 
Krnjevic, K., and S. Schwartz (1967) Some properties of unresponsive cells in the cerebral cortex. Exp. Brain Res. 3: 306-319.

MacVicar, B. A., S. A. Crichton, D. M. Burnard, and F. W. Y. Tse (1987) Phorbol ester induced endogenous membrane conductance oscillations in astrocytes. Nature 329: 242-243.

MacVicar, B. A., K. Baker, and S. A. Crichton (1988) Kainic acid evokes a potassium efflux from astrocytes. Neuroscience 25: 721725.

McCarthy, D. D., and J. De Vellis (1980) Preparation of separate astroglial and oligodendroglial cell-cultures from rat cerebral tissue. J. Cell. Biol. 85: 890-902.

Müller, W., U. Misgeld, and H. D. Lux (1988) GABA mediated ion movements in the guinea pig hippocampal slice. Pflügers Arch. (Suppl.) 411: R149.

Nadler, J. V., B. W. Perry, and C. W. Cotman (1978) Preferential vulnerability of hippocampus to intraventricular kainic acid. In Kainic Acid as a Tool in Neurobiology, E. G. McGeer, J. W. Olney, and P. L. McGeer, eds., pp. 219-237, Raven, New York.
Reynolds, R., and N. Herschkowitz (1984) Uptake of [ $\left.{ }^{3} \mathrm{H}\right]$ GABA by oligodendrocytes in dissociated brain cell culture: A combined autoradiographic and immunocytochemical study. Brain Res. 322: 1731 .

Schousboe, A. (1981) Transport and metabolism of glutamate and GABA in neurons and glial cells. Int. Rev. Neurobiol. 22: 1-45.

Shon, F., and Kelly, J. S. (1974) The characterization of $\left[\mathrm{H}^{3}\right]$ GABA uptake into satellite glial cells of rat sensory ganglia. Brain Res. 66: 289-300.

Stewart, W. W. (1981) Lucifer dyes-highly fluorescent dyes for biological tracing. Nature 292: 17-21.

Study, R. E., and J. L. Barker (1981) Diazepam and (-)pentobarbital fluxuation analysis reveals different mechanisms for potentiation of gamma-aminobutyric acid responses in cultured central neurons. Proc. Natl. Acad. Sci. USA 78: 7180-7184.

White, W. F., and S. R. Snodgrass (1979) Isoguavacine binding uptake and release: Relation to the GABA system. I. Neurochem. 33: 181189. 